DOI 10.31558/1815-3070.2018.36.8

УДК $811.111^{\prime} 42: 159.942$

\title{
ПРИНЦИПИ ЛІНГВІСТИЧНОГО КОНСТРУЮВАННЯ ЕМОЦІЙ У ДИСКУРСІ
}

У статті висвітлено основні аспекти, згідно яких відбувається конструювання емоцій у дискурсі, а саме залучення соціокультурних чинників, побудова типової комунікативної ситуації $i$ вибір відповідних лінгвальних засобів. Процес конструювання емоцій у дискурсі постає як процес взаємодї когнітивних, ситуативних і соиіально-культурних чинників, зумовлений характеристиками емоцій як психологічних процесів. У статті, опираючись на лінгвістичну конструктивістську теорію емоцій, здійснено контекстуальний, дискурсивний аналіз та контент-аналіз об'єктивації емоиії в дискурсі на основі дистресу (distress) 6 англомовному медіа-дискурсі. У результаті, виокремлено соціокультурні чинники конструювання дистресу й типові предметно-референтні ситуації, залучені для трансляції емоиійного смислу. cumyauiя.

Ключові слова: дискурс, емоція, комунікативна ситуачія, конструювання, предметно-референтна

Постановка проблеми. Когнітивно-дискурсивний підхід до вивчення емоцій зосереджує увагу на суспільній природі емоцій і їх культурно-специфічних аспектах. Емоції постійно залучені у комунікацію і тому $\epsilon$ динамічними сконструйованими інтерактивними процесами. Форму і зміст емоцій як соціальних конструктів визначають контексти, які містять суб'єктивну оцінку учасниками комунікації подій і відображають функціональні характеристики емоцій як психобіологічного, соціального і культурного адаптаційного механізму. Емоції завжди спрямовані на об'єкт, що є проявом їх інтенційності, вони культурно-специфічні (Barret), так як відображають поняття норми, характерне для певної спільноти і пов'язані з оцінкою ситуації як сприятливою/несприятливою для індивіда. Тому вивчення ролі емоцій е комунікативній взаємодії через дослідження їх ролі в побудові дискурсу є актуальним.

Аналіз останніх досліджень і публікацій. Теорія конструювання емоцій бере свій початок 3 часів Стародавньої Греції, коли філософ Геракліт стверджував, що «ніхто не увійде в одну річку двічі», тому що лише розум сприймає постійно мінливу річку, як чітке «тіло» води (Barrett 32). Соціальний конструктивізм як напрямок дослідження емоцій з'явився у психологічній науці з метою вивчення ролі соціальних цінностей у процесі взаємодії в соціумі і в подальшому знайшов свій розвиток в лінгвістичних студіях. Теорія конструктивізму наголошує на тому, що емоції формуються в той момент, коли відбуваються біологічні процеси у людському мозку і тілі. Увага зосереджена на тому факті, що емоції хоча і біологічно керовані природні явища, але здатні бути підпорядковані соціальним правилам, керовані ними і тому соціально сконструйовані. Процес конструювання відбувається через культурні норми, власний досвід людини і ситуаційні чинники (Lewis et al. 1-20).

Теорія конструювання емоцій базується на трьох принципах: соціальному конструктивізмі, який акцентує увагу на важливості ролі соціокультурних чинників, психологічному конструктивізмі, згідно якого емоції будуються базовими системами головного мозку і тіла, і нейроконструктивізмі, визнаючи ідею, що досвід створює зв'язки в головному мозку (Barrett 32). Л. Баррет, одна з сучасних представників напрямку конструктивізму, стверджує, що емоції не є реакцією на світ, так як людина не є пасивним отримувачем сенсорних відчуттів, але активним конструктором емоцій. Грунтуючись на чуттєвому відчутті і минулому досвіді, людський мозок конструює емоційний смисл і прописує дію (Barrett 31).

Ідея соціального конструювання знайшла свою реалізацію в лінгвістичній конструктивістській теорії емоцій. Лінгвістичний підхід зосереджує увагу на пошуку відповіді на запитання як емоції є конструйованими в мові і чому в різних ситуаціях конструювання індивідом однієї і тієї ж емоції відбувається по-іншому. Поштовхом до виникнення теорії слугувало питання: чому люди, коли їх прохають розказати як вони або хтось інший почувається, конструюють обставини подій або ситуацій, і в той же час, коли їм потрібно сконструювати обставини подій, вони повідомляють про свої емоції (Bamberg). Емоції, на думку американського дослідника М. Бамберга, $є$ перш за все дискурсивні, а мова $є$ засобом конструювання емоційного смислу і може бути використана як засіб для вивчення світу емоцій. Емоції є тими індексами, які вказують на намір мовця i реконструкція емоційного смислу слухачем вимагає інференційного умовиводу, тобто розуміння когнітивних, соціальних, культурних аспектів, які супроводжують висловлення (Bamberg 314-317). Для конструювання емоцій важливими є когнітивні сценарії з урахуванням саме ситуативного чинника, в основі якого лежать інтенційне маркування дії, поведінкові характеристики, транзитивність і справедливість дії. (Ватberg). Дискурсивний підхід робить акцент на розумінні емоцій як особливих соціальних подіях, пов'язаних 3 певною ситуацією (Harre), що дозволяє розглядати емоції як соціальний конструкт.

Таким чином, емоції в своєму різноманітті проявів тісно пов'язані зі специфічною ситуацією, їх фізична маніфестація різниться також в залежності від картини світу, яка існує в свідомості людини і того, як вона категоризує його. Соціальне конструювання емоцій зумовлене певними характеристиками емоцій як

(C) Крисанова Т.А., Вербицька А.Е., 2018 
психологічних процесів, а саме ситуативним характером, соціальною і культурною детермінованістю, нерозривним зв'язком із когнітивними процесами.

Метою дослідження постає виділення принципів лінгвістичного конструювання емоцій в дискурсі. Досягнення поставленої мети передбачає виконання таких завдань: виокремити соціокультурні чинники конструювання, виділити предметно-референтні ситуації, проаналізувати лінгвальні засоби, залучені для трансляції емоційного смислу.

Матеріал дослідження становить корпус медіа-текстів загальною кількістю 47000 слововживань із 17 різножанрових електронних видань письмового англомовного медіа-дискурсу за 2006-2017 pp. (aнгл. Daily Express, Daily Mirror, The Guardian, The Independent, The Observer, The Telegraph, The Wall Street Journal, The Seattle Times, Evening Standard, Metro, Dunfermline Press, BBC News, CBC News, Salon, NewsFix, openDemocracy, European Jewish Congress). Методами дослідження є контекстуальний аналіз для визначення мовних засобів конструювання емоції в англомовному медіа-дискурсі; дискурсивний аналіз та контент-аналіз для встановлення якісних і кількісних характеристик медіа-дискурсу, а саме соціального контексту, у який занурена комунікативна ситуація дистресу, за допомогою програмного забезпечення Техtanz, опції Concordance; когнітивно-дискурсивна інтерпретація для ідентифікації дискурсивного фрагмента.

Основні результати дослідження. Лінгвістичне конструювання емоцій у дискурсі є динамічним процесом, який розгортається залежно від комунікативної взаємодії та відносин комунікантів, що відбуваються в межах широкого соціокультурного контексту. Відносини між дискурсом і суспільством, як стверджує Т. ван Дейк, соціально опосередковані комунікативною ситуацією, так як вони сконструйовані комунікантами. Використання мови соціально, особистісно і ситуаційно варіативне, що спричинено досвідом індивіда в кожній конкретній ситуації. Існування універсаліїв людських мов уможливлює виділення універсаліїв людської когніції і інтеракції, організованих в межах певних моделей (Van Dijk 251). Різні ситуації будуть провокувати різне конструювання емоції в залежності від об'єкту емоції, контекстуальних чинників і попереднього досвіду. Для лінгвістичного конструювання емоцій в дискурсі релевантними $є$ залучення соціально-культурних чинників, які відображатимуть цінності, важливі для певної лінгвокультурі; виділення типових комунікативних ситуацій через які буде відбуватись трансляція цих цінностей і використання відповідних лінгвальних засобів. За допомогою зазначених трьох компонентів відбувається конструювання емоцій в дискурсі як динамічних конструктів.

3 метою ілюстрації вищезазначеного твердження у статті, особливості конструювання емоцій простежено на матеріалі емоції дистресу в медіа-дискурсі із залученням програми Textanz (oпція Concordance). Дистрес (distress), який виокремлюють як базову емоцію представники психологічних студій (Izard, Tomkins), визначений як психічний стан емоційної напруги, що характеризований високим ступенем вираженості, інтенсивності й тривалості (Selye). Залучення дистресу в медіа-дискурсі слугує засобом створення емоційного наповнення тестів 3МI, їх вираженої емотивності, активації в свідомості адресата категоріальних емоційнонегативних ситуацій. Його актуалізація відбувається в комунікативній ситуації, де адресант - автор конструює й транслює дистрес читацькій аудиторії - адресату для емоційної рефлексії на події в суспільстві за допомогою предметно-референтних ситуацій (термін - (Makarov 159)), характерних для виникнення і переживання дистресу. Комунікативною є ситуація, у якій суб’єкти здійснюють комунікативну взаємодію, а предметнореферентною - ситуація, що є темою розмови (Morozova 180).

У результаті аналізу одиничних висловлень і повторюваних слововживань за допомогою програми Textanz нами виявлено такі соціокультурні чинники, які проявляються в комунікативній і предметнореферентних ситуаціях дистресу й визначають особливості його конструювання: «сім'я», «смерть», «життя», «свобода», «справедливість», «підтримка», «надія», «правда» та «час» (Verbytska).

Однією з основних цінностей англомовного суспільства виступає «сім'я» (Semeniuk and Parashchuk 148), яку традиційно розглядали як «притулок» від турбот світу, а вихід 3 якої означає самотність, нещастя та соціальну нестабільність. Сім'я виступає як єдність, як люди, котрі входять в одну спільноту (англ. we as a family shared that love; part of our family; the cricketing family), у якій емоційний стан одного члена залежить від емоційного стану всього колективу й навпаки. Сім'я також виступає як підтримка суб'єкта дистресу (англ. families on front line of soldiers' distress; family pays tribute).

Увагу акцентовано на важливості любові й уваги матері для емоційного здоров'я дитини (англ. the young child grew up without a mother's love and never enjoyed her childhood days; gave her advice and love as a mother; she can get a mother's advice, attention and love), нестача або відсутність яких призводить до страждання. Розглянемо приклади:

(1) англ. Though Belgian Evaluation Commission for Euthanasia says $<\ldots>$ individuals can also apply based on emotional suffering. $<\ldots>$ Verhelst described growing up as a girl in an unloving family that had wished for a boy. $<\ldots>$ Verhelst's history suggests a life that was marred by extreme mental pain, much of which could have been defused had he been treated with more understanding and compassion from the beginning (Salon, Oct 8, 2013).

Фрагмент предметно-референтної ситуації «Моральне насильство» ілюструє випадок із дівчинкою, котра виросла в сім’ї без любові. Байдужість матері підштовхнула ії змінити стать і пізніше вдатися до евтаназії. Дистрес конструйовано за допомогою іменників (англ. suffering, pain) та прикметників, які підкреслюють вплив саме на психоемоційну сферу суб'єкта дистресу (англ. emotional, mental), переживання інтенсифіковано за допомогою прикметника (англ. extreme). 
(2) англ. During her detention, this mother's ten year old son was receiving support from a mental health service, who described him as 'incredibly distressed' about her absence. Children's Services said that 'the current situation where [his mother] is not living in the family home has resulted in him feeling unsafe' (openDemocracy, 6 May 2013).

У зазначеному прикладі предметно-референтної ситуації «Розлука матері з дитиною» втрату душевного спокою суб'єктом дистресу конструйовано словосполученням англ. feeling unsafe, а високий ступінь інтенсивності емоції виражений лексемою англ. incredibly.

Сполучуваність мовних одиниць уточнює зв'язок між дистресом і «смертю» в медіа-дискурсі, а саме, причиною дистресу є смерть дітей, рідних та улюблених знаменитостей (англ. the death of a child; infant death; by their hero's death; Diana's death; her grandfather died; traumatized by the death; shattered over death), переживання дистресу через розірвані стосунки порівнюють зі смертю (англ. I mourned my marriage like a death). Негативний вплив емоційного стану людини провокує іiі на суїцидальні думки або асистовану смерть (англ. desire to end life; another human being end it [life]).

(3) англ. 'Shocked and devastated' Family's outpouring of grief as man shot in Libya is named. THE family of a British man who was shot dead in Libya have spoken of their "shock" and "devastation" at his killing today (Daily Express, January 5, 2014).

У фрагменті предметно-референтної ситуації дистресу «Втрата» конструювання адресантом дистресу відбувається через апеляцію до душевного стану членів сім'ї загиблого в Лівії (англ. shocked, devastated, grieving, sadly). Емоційність емпатії висвітлена метафоричністю образу душевного переживання емоції як спустошення (англ. devastated), потоку, який виливається з контейнера (англ. outpouring of grief). Синекдоха (англ. family), уживання роду замість виду - сім’ї замість ії членів, денотує дистрес усіх, хто належить до родини.

Конструювання дистресу в медіа-дискурсі відбувається через образ зруйнованого, спотвореного, нестерпного, розбитого «життя» людини, котра перебуває в стані дистресу (англ. a life that was marred; made her life unbearable; can't handle life; he's ruined my life; every aspect of my life was broken; totally finished my life as I know; destroyed the life; who ruined lecturer's life with her lies; life was disrupted), яка для припинення страждань прагне покінчити з ним (англ. ends his life; deliberately ended his life; desire to end life). Однак, незважаючи на фатальність ситуації дистресу (англ. the arbiter of life and death; life itself is left to chance; the life and fate of; irreversible damage; You'll lose everything, it's your wings or your life) та створення в медіа негативного образу безладу, складності й дикості життя (20 відповідників), у якому людина не може не відчувати дистрес (наприклад: англ. wildness of life; it is indeed a topsy-turvy world in which we live; life is never easy), присутні також позитивні уявлення (13 відповідників), що формують цінність успішного, сповненого смислу життя та право людини обирати (англ. уои have to get on with your life; life-chances; meaningful life; successful life; to cling to life). Наприклад:

(4) англ. I know what it is to feel hungry and to see your child go hungry. It's a life of turning off the fridge because it's empty anyway, of sitting across the table from your young son enviously staring down at his breakfast. Of having freezing cold showers and putting your child to bed in god knows how many layers of clothes in the evening. It's distressing. Depressing. Destabilising. $<\ldots>$. Parents are looking at empty cupboards in despair (Daily Mirror, Feb 24, 2014).

У наведеному фрагменті предметно-референтної ситуації «Скрутне становище» автор фокусує увагу на власному негативному досвіді страждань через нестачу їжі. Психічна нестійкість відображена у реченняхacepтивах (англ. it feels) та експресивах у формі еліптичних речень (англ. It's distressing. Depressing. Destabilising.). Автор стверджує спільність поглядів / потреб із читачем, змальовує умови виникнення дистресу за допомогою анафори прийменника англ. of та синтаксичної структури англ. it's.

В англомовному медіа-дискурсі наскрізним виступає поняття «свобода» як найвища цінність, а іiі відсутність - як джерело сильного горя й страждання. Свобода для носіїв англомовної культури означає право та можливість робити, що хочеш (без контролю чи обмеження з боку будь-кого), та стан бути вільним (не рабом чи ув'язненим) (Semeniuk and Parashchuk). Відповідно, будь-які зовнішні або внутрішні чинники, що обмежують це право й нівелюють стан свободи, виступають джерелом дистресу для суб'єкта. У корпусі медіатекстів виявлено словоформи та висловлення, що експлікують відсутність:

1) «зовнішньої свободи», а саме: ув'язнення, утримання під арештом, наглядачів, затриманих осіб, депортації, застосування сили, потрапляння в пастку, облогу (англ. detention; detained; detainee; restrain; restraining; restraint; forcibly; guards; holding; escort; deportation; deport; deported; deportee; deporting; removal; removed; removing; captive; captivity; kept; keeping; keepers; stranded; people are trapped; incarcerated; trapped in besieged areas).

Прикладом обмеження зовнішньої свободи є предметно-референтна ситуація дистресу «Небезпечна ситуація». Автор відзначає зростаючий рівень дистресу серед дітей і повідомляє про джерело емоції - узяту в облогу територію, із якої неможливо вибратись:

(5) англ. Authors of the study $<\ldots>$ warned the nation's mental health crisis had reached a tipping point, where "staggering levels" of trauma and distress among children could cause permanent and irreversible damage. $<\ldots>$. About 4.8 million people are trapped in besieged and hard-to-reach areas (The Guardian, 6 March 2017); 
2) «внутрішньої свободи», яку пояснюють у філософії як «звільнення людини всередині себе від оковів/пут власних упереджень, уявлень та образів» (Danylian et al.). Причиною відсутності внутрішньої свободи є зовнішній подразник й усвідомлене рішення (за умови наявності вибору), прийняте людиною, розцінювати ситуацію як небажану, безвихідну, таку, що несе горе, страждання, біль. Прикладом обмеження «внутрішньої свободи», що призводить до дистресу, є предметно-референтна ситуація "Фрустрація», у якій автор повідомляє про крах планів щодо запланованого відпочинку через зовнішній подразник - затримку видачі документів:

(6) англ. I absolutely recognise the anger and distress that some people have suffered and I would like to put on record that yes, in every case where we haven't met our service standards, where we haven't been able to meet the customer's needs, yes, certainly, we are sorry for that (BBC News, 1 May 2014).

Комунікативна ситуація дистресу в медіа-дискурсі висвітлює духовну цінність «справедливість», що належить до «вищих універсальних цінностей та зливається 3 правосуддям в одному концепті в західному менталітеті» (Prykhodko 33). Суб’єкти дистресу вбачають засобом полегшення свого емоційного стану відновлення чи встановлення справедливості, покарання індукторів дистресу - явищ, об'єктів чи людей, які так чи інакше стали зовнішніми подразниками. «Справедливість» ідентифікують такі лінгвальні відповідники: англ. justice, no feeling of vengeance or retribution, justified, investigate / -d / -ion, reinvestigating, search / -ed, seeking, human rights, sentence, term, punished / -ment, term, extradite / -tion, unfair, deserves (to be punished). Наприклад, у фрагменті предметно-референтної ситуації «Фізичне насильство» модальне дієслово англ. should слугує мовним маркером диктування суб'єктом дистресу умов до покращення свого емоційного стану за рахунок відновлення справедливості, а саме засудження вбивці доньки до довічного ув'язнення:

(7) англ. Coral Jones, 42, said: "I'm really pleased that it has gone ahead and because people like him should never be allowed out. $\langle\ldots\rangle$. "Life should be life. I don't think they should have an easy life in prison where they have three meals a day. Perhaps years ago they had to earn stuff - today they have human rights. "Our rights went when he killed our daughter and we still suffer now and it's over a year" (Daily Mirror, Feb 23, 2014).

Контент-аналіз також виявляє соціокультурний чинник «підтримка», який експлікують контексти 3 ключовою лексемою-репрезентантом англ. support. Важливою $є$ пропозиція підтримки та співчуття (англ. support was being offered), іiї кількість (англ. not given enough support) і коректність відповідно до ситуації (англ. with the right support, children can recover; adequate adult support). Визначним елементом виходу зі стану дистресу та найбільшою підтримкою для суб'єкту дистресу постає сім'я, для дітей - батьки / дорослі (англ. children experience strong or prolonged adversity without adequate adult support; family support structures). Підтримку сім'єю іï члена метафорично передано як боротьбу на лінії фронту або пробирання крізь мінне поле в предметно-референтній ситуації «Хвороба, недуга чи поранення»:

(8) англ. When a soldier suffers from PTSD, families, particularly spouses such as Paxton, are on the front line of it $\langle\ldots\rangle$. So some families and spouses slog through this minefield on their own, or depend on close relatives and friends (The Seattle Times, March 19, 2012).

Універсальна духовна цінність «надія», що матеріалізована в складі тріади концептів «ВІРА-НАДІЯЛЮБОВ» (Prykhodko 83), має істотну значущість як помічника, який визволить суб'єкта від страждань або полегшить його горе: англ. I hope; hoping it would go away; hopelessness and apprehension about their future; vain hope; false hope. Страждання суб'єкта дистресу посилюють: 1) відчуття безнадійності / безвихідності / відчаю, наприклад у фрагменті:

(9) англ. < .. > a combination of factors < .. > make them predisposed to heightened distress when faced with hopelessness, and apprehension about their future” (The Guardian, 18 January 2016);

2) вселення примарної надії, зокрема, на повернення зниклої дитини. У цьому випадку відбувається подвійна емоційна реакція на негативну подію:

(10) англ. "It is distress heaped upon tragedy to learn that the News of the World had no humanity at such a terrible time. The fact that they were prepared to act in such a heinous way that could have jeopardised the police investigation and give them false hope is despicable" (The Guardian, 4 July 2011).

У фрагменті предметно-референтної ситуації «Моральне насильство» адресант засуджує втручання журналістами у приватне життя, визнає жалюгідним, жахливим, безжалісним (англ. despicable; heinous; no humanity) подання марної надії суб'єктові дистресу. Фрагмент виявляє каскадність емоції, тобто іiі інтенсифікацію внаслідок тривалого накопичення неприємних подій (англ. It is distress heaped upon tragedy).

Учасники ситуації дистресу сподіваються на підтримку, відновлення справедливості (англ. he hoped that "justice would prevail"), уникнення смертей та інших утрат (англ. I can only hope that this does not lead to unnecessary loss of life in the future; hope it's not a mortal disease), повернення рідних (англ. caused her parents to have false hopes that she was alive), «хепі-енд» - щасливе завершення сюжетних ліній для позитивних персонажів (англ. she hopes that the bad beginning in her life will make a good ending), у позитивні зміни, щоб не допустити повтору трагічних подій (англ. I sincerely hope changes are made to make sure no family has to go through the pain that Sheila's family are currently experiencing), звільнення від страждання / вихід зі стану дистресу (англ. the hope that in the end, she found a release from the mental torment that made her life unbearable), відновлення після дистресу (англ. I was suffering a lot. Too much. <... I hope to recover myself).

Соціокультурний чинник «правда» втілений автором через указівку на його антипод - «брехню» або «містифікацію» («витівка, вигадка 3 метою ввести кого-небудь в оману жартома чи із злим наміром»), 
об’єктивовану лексемами й словосполученнями: англ. lies; lie detector; be duped («залишитися в дурнях»); англ. fraud («обман; ошуканство»); англ. fraudulently («шахрайським способом»); англ. fake (n. «підробка, фальшивка»; adj. «удаваний; фальшивий»; v. «фальсифікувати; шахраювати, обманювати»); англ. fictitious; pretending; англ. prank («витівка; жарт»); англ. fantasist («фантаст»).

(11) англ. The father of a callous fantasist who destroyed the life of her lecturer by pretending she had terminal cancer to make her care for her has said she "deserves to be punished". Elisa Bianco, 22, was sentenced to two years and eight months in prison last week after admitting she stalked and caused serious harm or distress to Sally Retallack (Independent, 22 December 2015).

У зазначеному фрагменті предметно-референтної ситуації дистресу «Моральне насильство» конструювання дистресу відбувається через засудження обману дівчинки, за допомогою емотиву англ. callous («безсердечний, бездушний, нечуйний»), й указання на наслідки брехні для емоційного стану ㄲï суб'єкта (англ. destroyed the life; serious harm or distress).

Соціокультурний чинник «час» денотують лексеми англ. time, minutes, hours, now, every day, long. Час відіграє визначальну роль, оскільки від нього залежить інтенсивність, уникання :: неуникання та полегшення дистресу. Наприклад, у фрагменті предметно-референтної ситуації «Фізичне насильство» зображено залежність емоційного стану від тривалості перебування в ув'язненні:

(12) англ. People held in immigration detention have rates of severe mental distress. < ... Detainees' mental health is deteriorating dramatically the longer they are incarcerated (The Guardian, 18 January 2016).

Час визначає перехід від потенційної до реальної можливості входу в стан дистресу. У фрагменті предметно-референтної ситуації «Хвороба, недуга чи поранення» зображено залежність часу перебування мозку без кисню й катастрофічних наслідків для життя дитини, яка в подальшому виконуватиме роль суб'єкта та об'єкта дистресу для своїх рідних:

(13) англ. There were warning signs from about an hour before Toby was born to show that he was in distress. $<\ldots>$ The midwife's mistakes mean that Toby was not finally born until 20-25 minutes after he should have been, during which time his brain was starved of oxygen. <... Toby's brain damage, which happened during those last 20-25 minutes and which was catastrophic" (The Guardian, 14 April 2011).

Час виконує також функцію дейксису, денотує момент перебування суб'єкта в стані дистресу (англ. the time I was rather nonplussed) та стан або оцінку (англ. at this distressing time).

Висновки і перспективи. Процес конструювання емоцій у дискурсі постає як процес взаємодії когнітивних, ситуативних і соціально-культурних чинників, що знаходить свою реалізацію в мовній формі. Процес конструювання емоцій в дискурсі відбувається в межах трьох-компонентної моделі: залучення соціокультурних чинників, побудова типової комунікативної ситуації і вибір відповідних лінгвальних засобів. Для конструювання дистресу в медіа-дискурсі залучені соціокультурні чинники, важливі для представників англомовної спільноти: «сім'я», «смерть», «життя», «свобода», «справедливість», «підтримка», «надія», «правда» та «час». Типовими предметно-референтними ситуаціями є «Втрата», «Фрустрація», «Розлука матері 3 дитиною», «Хвороба, недуга чи поранення», «Моральне насильство», «Фізичне насильство», «Скрутне становище» та «Небезпечна ситуація». Лінгвальні засоби представлені лексичними одиницями, які містять у своїй семантичній структурі емотивно-оцінний компонент, лексемами-репрезентантами емоцій, лексичними і синтаксичними засобами інтенсифікації. Перспективним є виділення стратегій конструювання емоцій в різних типах дискурсу.

\section{References}

Bamberg, Michael. "Language, Concepts and Emotions: the Role of Language in the Construction of Emotions." Language Sciences 19, No. 4 (1997): 309-340. Print.

Barrett, Lisa Feldman. How Emotions are Made. The Secret Life of the Brain. Boston, New York: Houghton Mifflin Harcout, 2017. Print.

Danylian, Oleh, Dzioban, Oleksandr, Maksymov, Serhii, et. al. Filosofia Prava (The Philosophy of Law). Kharkiv: Pravo, 2009. Print.

Dijk, Teun A. van. Society and Discourse. How Social Contexts Influence Text and Talk. Cambridge University Press: Cambridge, 2009. Print.

Harre, Rom, and W. Gerrod Parrot. The Emotions: Social, Cultural and Biological Dimensions. London: Sage Publications, 1999. Print.

Izard, Carroll Ellis. The Psychology of Emotions. New York: Plenum, 1991. Print.

Lewis, Michael, and Carolyn Saarni. "Culture of emotions." The Socialisation of Emotions. NY/London (1985): 1-20. Print.

Makarov, Mikhail. Osnovy Teorii Diskursa (The Basics of Discourse Theory). Moscow: Gnozis, 2003. Print.

Morozova, Olena. "Interakziinyi Freim jak Struktura Komunikatyvno Relevantnoho Znannia: Teoretychnyi ta Innovaziinyi Aspekty (The Interaction Frame as a Structure of Communicatively Relevant Knowledge: Theoretical and Didactic Aspects)". Suchasni fundamentalni teorii ta innovatsiini praktyky navchannia inozemnoi movy u vuzi (Modern Fundamental Theories and Innovative Practices of Teaching Foreign Language in HEI). Kharkiv, 2013. 177-190. Print. Prykhodko, Anatoli. Konzepty i Konzeptosistiemy (Concepts and Conceptosystems). Dnipropetrovsk, 2013. Print. 
Semeniuk, Oleh and Valentyna Parashchuk. Osnovy Teorii Movnoi Komunikazii (The Basics of the Communication Theory). Kyiv: VZ “Akademia”. 2010. Print.

Tomkins, Silvan Solomon. Affect Imagery Consciousness. USA: Springer Publishing Company. 1963. Print.

Verbytska, Anna. "Konzept DYSTRES/DISTRESS v anhlomovnomu media dyskursi: kohnityvnokomunikatyvnyi aspekt (The Concept DISTRESS in English Media Discourse: Cognitive and Communicative Aspects)". Diss. V.N. Karazin Kharkiv National University, 2018. Abstract. Print.

Salon. Web. URL: https://www.salon.com/

\title{
List of Sources
}

openDemocracy. Web. URL: https://www.opendemocracy.net/

Daily Express. Web. URL: https://www.express.co.uk/

Daily Mirror. Web. URL: https://www.mirror.co.uk/

The Guardian. Web. URL: https://www.theguardian.com/us

BBC News. Web. URL: https://www.bbc.com/news

The Seattle Times. Web. URL: https://www.seattletimes.com/

Independent. Web. URL: https://www.independent.co.uk/

Надійшла до редакції 20 листопада 2018 року.

\section{THE PRINCIPLES OF LINGUISTIC CONSTRUCTING EMOTIONS IN DISCOURSE}

Tetiana Krysanova, Anna Verbytska Conversational English Department,

Lesya Ukrainka Eastern European National University, Lutsk, Ukraine

\section{Abstract}

Background: Norms of society govern emotions transforming them from purely biological into social constructs. Emotions in their diversity of manifestations are closely related to a specific situation, their physical manifestation also varies depending on the picture of the world that exists in the minds of individuals and its categorization. Thus, the current paper sheds light on the principles of constructing emotions is discourse based on psychological and linguistic theories of constructed emotions. Linguistic theory of constructed emotions pinpoints emotions as discursive phenomena, as indices indicating the speaker's intention. Reconstruction of emotive implications requires inferences, that is, the understanding of cognitive, social, and cultural aspects accompanying narration.

Purpose: The purpose of analysis is to define principles by which emotions are constructed in discourse. The objectives of this paper are the following: to distinguish socio-cultural features of emotions constructing on the basis of distress in media discourse; to reveal particular reference situations involved into a process of transmitting emotive implications.

Results emerge from a contextual analysis, a discourse analysis and a content analysis (Textanz software, Concordance option) of 17 electronic editions of written English media discourse of different genres for the period of 2006-2017. Findings encompass nine socio-cultural features of constructing distress as a feeling of extreme unhappiness: 'family', 'death', 'life', 'freedom', 'justice', 'support', 'hope', 'truth', 'time'. The analyses elicited the following reference situations which frame the embodied emotion socially and culturally: 'Loss', 'Maternal and childbirth separation', 'Frustration', 'Illness, disorder, or injury', 'Difficult situation', 'Physical violence', 'Moral violence', 'Dangerous situation'.

Discussion: The process of constructing emotions in discourse moves on to the interaction of cognitive, physiological, situational, and socio-cultural features and manifests itself in discourse through language. Prospects for further investigations embrace strategies of constructing emotions in different types of discourse.
\end{abstract}

Keywords: a communicative situation, constructing, discourse, an emotion, a reference situation.

Vitae

Tetiana Krysanova is Ph. D. in Philology, Associate Professor at the Conversational English Department, Lesya Ukrainka Eastern European National University. Her areas of research interests include cognitive linguistics, communicative linguistics, discourse theory.

Correspondence: kobeka72@gmail.com

Anna Verbytska is a full-time teacher at the Conversational English Department, Lesya Ukrainka Eastern European National University. Her areas of research interests include cognitive linguistics, communicative linguistics, media linguistics, discourse theory.

Correspondence: engannalish@gmail.com 